\title{
Increasing Academic Performance Through Android- Based Accounting Cycle Learning Applications
}

\author{
Nyoman Trisna Herawati ${ }^{1{ }^{*}}$ Edy Sujana ${ }^{1}$ Luh Gede Kusuma Dewi ${ }^{1}$
}

\author{
${ }^{1}$ Department of Economics and Accounting, Universitas Pendidikan Ganesha. Singaraja, Indonesia \\ *Corresponding author. Email: trisnaherawati@undiksha.ac.id
}

\begin{abstract}
This aims of this study is to develop an android-based accounting cycle learning media. On the previous year, has developed learning media that are declared feasible to use by expert judges. This year, the research continued with field testing on accounting students who is taking introductory accounting courses. This study examines differences in academic performance as seen from student learning outcomes and motivation. The research method uses an experiment with a post-test control group design. The data analysis technique used descriptive statistical analysis and the Mann Whitney test. The test results show that the experimental class learning outcomes are better than the control class with an average value of $71.9>63.4$. Likewise, learning motivation showed a significant difference. This study shows that the use of technology-based learning media can improve the performance of learning outcomes and make learning more interesting and fun.
\end{abstract}

Keywords: Android Learning Media, Accounting Cycle, Academic Performance.

\section{INTRODUCTION}

One of the sectors affected by the Covid-19 pandemic is education. Almost all schools and universities in Indonesia enforce online learning policies. In practice, online learning brings its own challenges for students and teachers. In universities, which usually already have an digital learning system or Learning Management System (LMS), it still requires greater effort. I its intended that learning materials can be delivered properly. Likewise, students must prepare themselves both materially, energy, and psychological readiness, so that they can receive the material optimally [1].

Online learning during the Pandemic, forcing all lecturers and students to use technology in their learning. Initially learning using technology is often ignored, because not everyone is ready or literate with technology. However, with the pandemic, inevitably all students must use technology. This actually supports the need for technological literacy that must be mastered by students. Technological literacy can be defined as the ability to use, understand, manage, and evaluate an innovation that involves processes and knowledge to solve problems and expand one's abilities [2]. For this reason, the use of technology in supporting learning is very necessary, so that students have skills in using technology which in turn are able to create the technology itself.

One of the technologies in the field of learning is the use of media that is operated on a smartphone device with an android system. Currently, the use of smartphones in learning, especially those based on Android, is very popular with the public, in this case students [3]. This is evident from the massive growth of online learning applications such as Ruangguru.com, quipper.com, and other learning applications that can be downloaded for free on the platforms. This shows that there has been a shift in student interest in understanding a material. The survey results show that many Indonesian students use technology in the classroom, compared to students in other developed countries. Research conducted by an educational organization in Cambridge found that Indonesian students use technology in the classroom more than 40 percent of other countries. This figure ranks second highest after the United States, which is as much as $54 \%$. In addition, more than two thirds of students in Indonesia or as much as $67 \%$ use smartphones in class and even more or as many as $81 \%$ use them to do homework [4].

The use of android-based learning media is one way to improve technological literacy among students. Basically, the use of on-line learning media is proven to be able to improve academic achievement and student motivation [5] [3] [6] [7]. Implementation of learning using smartphones and tablets can have a positive impact not only on cognitive abilities, but also on metacognitive, affective and socio-cultural domains. Smartphone and tablet media have the advantage of transforming learning experiences into real practice in the field. In addition, 
smartphone and tablet-based learning media are able to prepare and receive material anywhere at a time that can be arranged by the user, so that it can increase motivation in learning.

This study develops device-based learning media with the Android operating system in an introductory accounting course. The material in the introductory accounting course is to understand the accounting cycle starting from the recording transaction to prepare financial statements. Several studies have shown that many students have difficulty understanding the accounting cycle due to a long process, and understanding accounts or accounts which are quite complicated [8]. This implies the need for changes in the design, methods, and curriculum for accounting learning [9].

The learning media developed in this study is called the sikkaundiksha application. To start, students can log in through an account that has been entered first by the program administrator, in this case the lecturer or the class coordinator. The features in this application include the menu to create an account. In this feature, students are required to understand the correct account classification, account name, and account number. Next is the journal entry feature. Here, students are required to understand recording with the concept of an account, namely double entry. The journal entry stage in the sikka application, starting from entering the date of the transaction, then selecting the type of transaction including, cash out, cash in, sales, purchases, adjustments, or other transactions. Then enter the debit and credit accounts. Here, it is very important for students to understand how to analyze transactions using accounting methods or debit credit and normal balance rules. Next, this application also introduces cash flow in a simple way. Students determine whether cash transactions are included in operating, investing, or financing activities. The final stage in journal entry is to enter the nominal value and description or description of the journal. Furthermore, the application will perform transaction processing automatically and the user just clicks on the financial statements presented [10].

So far, introductory accounting lessons have focused more on understanding theories and cases [11]. However, the use of technology in lectures is still rarely done. Even though nowadays there are many applications that support the material in the introduction to accounting, such as lamikro applications, cash books, book stalls, and other accounting applications. Based on this, this study initiated an application that provides a deeper understanding of accounting in the accounting cycle material, besides that later it can be applied directly in the preparation of simple financial statements for SMEs.

This research supports the learning process in the new curriculum which will be implemented in 2020. This curriculum provides opportunities for students to study outside the program, to develop skills and expertise in work. Sikkaundiksha application, helps students to be skilled in the use of financial technology, which can help students in internship. Based on the explanation above, this study aims to analyze student academic performance as seen from learning outcomes and learning motivation using android-based application media.

\section{METHOD}

This research is a research and development research that aims to develop a product and test the effectiveness of the product. The development model used is a modification of the 4-D Model by Thiagarajan, Semmel, \& Semmel in 1942 (by applying several stages, namely: define, design, and develop the product) [12]. Product validity development and testing have been carried out in the first year (2020). Furthermore, testing the effectiveness of the media was carried out by field trials on Undiksha Accounting S1 students who took the Introduction to Accounting course. Field trials using the experimental method with details of 62 people in the experimental class and 63 people in the control class. The experimental class is a class that is given learning by using the sikka application, and the control class without using an application. Data collection techniques used questionnaires for learning motivation and learning outcomes tests (cognitive tests) with the concept of account and journaling. Before using the instrument, the validity and reliability were tested with the results that all items were declared valid with the $r$ count criteria greater than $\mathrm{r}$ table $0.334(\mathrm{n}=35$, sig. $5 \%)$ and the reliability coefficient value > 0.6 [13]. Experimental tests (field trials) were used to test the effect of using learning applications on academic performance, namely learning motivation and learning outcomes. The experimental design used is the posttest control group design [13]. The significance of the difference in the increase in motivation and learning outcomes was analyzed by statistical tests ( $t$ test) if the data were normally distributed and the Mann Whitney test if the data were not normally distributed [14] [15]. All analyzes were performed with statistical package for social science (SPSS Version 16)

\section{RESULTS \& DISCUSSION}

In this section, the calculation of data analysis will be carried out based on the data that has been obtained during the research period. Data analysis consisted of two parts, namely descriptive analysis and comparative test analysis to examine the comparison of student learning outcomes and motivation between the control and experimental groups.

Descriptive analysis is used to know the general description of the variables in the study, namely learning outcomes which can be seen in Table 1 and learning motivation in Table 2 . 
Table 1. Description of Learning Outcomes between Experimental and Control Group

\begin{tabular}{|c|c|c|c|c|}
\hline \multicolumn{2}{|c|}{ Learning } & \multicolumn{2}{|c|}{ Group } & \multirow{2}{*}{ Total } \\
\cline { 2 - 4 } Outcomes & Experiment & Control & \\
\hline \multirow{2}{*}{$\begin{array}{c}\text { Very } \\
\text { Good }\end{array}$} & $\mathrm{n}$ & 16 & 5 & 21 \\
\cline { 2 - 5 } & $\%$ & $76 \%$ & $23.8 \%$ & $100 \%$ \\
\hline \multirow{2}{*}{ Good } & $\mathrm{n}$ & 23 & 22 & 45 \\
\cline { 2 - 5 } & $\%$ & $51.1 \%$ & $48.9 \%$ & $100 \%$ \\
\hline \multirow{2}{*}{$\begin{array}{c}\text { Good } \\
\text { Enough }\end{array}$} & $\mathrm{n}$ & 18 & 23 & 41 \\
\cline { 2 - 5 } Not & $\mathrm{n}$ & $43.9 \%$ & $56.1 \%$ & $100 \%$ \\
\cline { 2 - 5 } Good & $\%$ & $25.0 \%$ & $75.0 \%$ & $100 \%$ \\
\hline \multirow{2}{*}{ Bad } & $\mathrm{n}$ & 1 & 1 & 2 \\
\cline { 2 - 5 } & $\%$ & $50.0 \%$ & $50.0 \%$ & $100 \%$ \\
\hline \multirow{2}{*}{ Total } & $\mathrm{n}$ & 62 & 63 & 125 \\
\cline { 2 - 5 } & $\%$ & $49.6 \%$ & $50.4 \%$ & $100 \%$ \\
\hline
\end{tabular}

Learning outcomes scores were obtained from the posttest developed by the researcher with account concept and journal topics. Learning outcomes are divided into 5 categories, namely very good with a score range of $85-100$, good with a score of 70-84, good enough with a score range 65-74, not good with a score range 55-64, and bad catagories if the score is less than 55. Based on the results in the Table 1 it can be seen that in the experimental group the majority are in the good and very good category. While in the control group the majority were in the good and good enough category. This shows that on average the learning outcomes of the experimental class are better than the control class.

Furthermore, to test motivation to learn using a questionnaire with several indicators, namely: perseverance in completing the tasks given, tough in the face of difficulties, has independence in learning, shows interest or interest in problem solving, and does not get bored quickly in learning. The questionnaire was prepared on a 5-point Likert scale, with 10 questions. The results of the frequency distribution of learning motivation can be seen in Table 2 .

Table 2. Frequency Distribution of Learning Motivation between Experimental and Control Group

\begin{tabular}{|c|c|c|c|c|}
\hline \multirow{2}{*}{\multicolumn{2}{|c|}{$\begin{array}{l}\text { Learning } \\
\text { Motivation }\end{array}$}} & \multicolumn{2}{|c|}{ Group } & \multirow{2}{*}{ Total } \\
\hline & & Experiment & Control & \\
\hline \multirow[t]{2}{*}{ High } & $n$ & 59 & 54 & 113 \\
\hline & $\%$ & $52.2 \%$ & $47.8 \%$ & $100.0 \%$ \\
\hline \multirow[t]{2}{*}{ Average } & $\mathrm{n}$ & 3 & 7 & 10 \\
\hline & $\%$ & $30.0 \%$ & $70.0 \%$ & $100.0 \%$ \\
\hline \multirow[t]{2}{*}{ Low } & $\mathrm{n}$ & 0 & 2 & 2 \\
\hline & $\%$ & $0.0 \%$ & $100.0 \%$ & $100.0 \%$ \\
\hline \multirow[t]{2}{*}{ Total } & $\mathrm{n}$ & 62 & 63 & 125 \\
\hline & $\%$ & $49.6 \%$ & $50.4 \%$ & $100.0 \%$ \\
\hline
\end{tabular}

Learning motivation in this study is divided into 3 categories, namely high, medium and low. Based on the results in Table 2, it can be seen that both the experimental and control groups were in the high category. However, the distribution of high frequency in the experimental group was more than the control group.

Hypothesis testing was carried out by comparison test to calculate whether there were significant differences in learning outcomes and learning motivation between the experimental group and the control group. In calculating the comparison test, there are several data assumption tests that need to be carried out to find out what comparative test matches the characteristics of the data. The assumption test required is the normality and homogeneity test of the data. If the data has a normal distribution and homogeneous variance, then the comparison test will use an independent $t$ test. However, if one or both of these conditions are not met, the test will use the Mann Whitney test. In Table 3 it can be seen the results of the normality and homogeneity of the data in the experimental and control groups.

Table 3. Normality and Data Homogeneity Test Results

\begin{tabular}{|c|c|c|c|c|c|}
\hline \multirow{2}{*}{ Varian } & \multirow{2}{*}{ Group } & \multicolumn{2}{|c|}{ Normality Test } & \multicolumn{2}{|c|}{ Homogeneity Test } \\
\cline { 2 - 5 } & & $\mathrm{p}$-value & explanation & $\mathrm{p}$-value & explanation \\
\hline \multirow{2}{*}{$\begin{array}{c}\text { Learning } \\
\text { outcomes }\end{array}$} & Experiment & 0.056 & Normal & \multirow{2}{*}{0.673} & Homogeneous \\
\cline { 2 - 4 } & Control & 0.021 & Abnormal & & \\
\hline Motivation & Experiment & 0.000 & Abnormal & \multirow{2}{*}{0.012} & \multirow{2}{*}{ Inhomogeneous } \\
\cline { 2 - 4 } & Control & 0.000 & Abnormal & & \\
\hline
\end{tabular}

The data is said to have a normal distribution and homogeneous variance if the probability value is greater than 0.05. Meanwhile, if the value is less than 0.05, it means that it has an inhomogeneous distribution and variance. The normality test used is the Kolomogorv Smirnov test, this is because the number of samples exceeds 50 samples. 
Based on the calculation results, it can be seen that in the learning outcomes data only the experimental group has a normal distribution, while the control group has an abnormal distribution. Then the results of the homogeneity test show the p-value is greater than 0.05 , which is 0.673 , which means it has a homogeneous variance.
Different things are shown in the learning motivation data, where the data does not have a normal distribution in both the experimental and control groups and also does not have a homogeneous variance. Thus, the comparison test that fits this condition is the Mann Whitney test with the following results. The test results can be seen in Table 4 as follows.

Table 4. Test Results Comparison of Learning Outcomes and Learning Motivation between Experimental and Control Groups

\begin{tabular}{|c|c|c|c|c|}
\hline \multirow{2}{*}{ Variable } & \multicolumn{2}{|c|}{ Group } & \multirow{2}{*}{ p-value } & Conclusion \\
\cline { 2 - 3 } & Experiment & Control & & Significant \\
\hline \multicolumn{2}{|c|}{ Learning outcomes } & & 0.001 & \\
\hline Mean & 71.9 & 63.4 & & \\
\hline Std. Deviation & 13.7 & 14.1 & & \\
\hline Median & 72.5 & 65.0 & & \\
\hline Minimum & 35.0 & 35.0 & & Significant \\
\hline Maximum & 95.0 & 95.0 & & \\
\hline Motivation to learn & 45.7 & 42.3 & & \\
\hline Mean & 4.0 & 7.2 & & \\
\hline Std. Deviation & 47.0 & 44.0 & & \\
\hline Median & 32.0 & 12.0 & & \\
\hline Minimum & 50.0 & 50.0 & & \\
\hline Maximum & & & & \\
\hline
\end{tabular}

Information: Mann Whitney Test CI 95\%

The average value of the two sample groups is said to have a significant difference if the probability value of the comparison test has a value less than 0.05. Based on the results of the calculations in Table 4.4 above, it can be seen that the average value of learning outcomes in the experimental group is $71.9 \pm 13.7$ while the experimental group has an average of $63.4 \pm 14.1$. Statistically this difference is considered significant or has a significant difference. This can be seen from the p-value of 0.001 where this value is smaller than 0.05 .

The same condition is seen in the results of learning motivation where the average value of the experimental group is $45.7 \pm 4.0$ greater than the control group which has an average of $42.3 \pm 7.2$. Statistically this difference is considered significant or has a significant difference. This can be seen from the p-value of 0.001 where this value is smaller than 0.05 . Thus, it can be concluded that there are significant differences in learning outcomes and learning motivation between the control and experimental groups $(\mathrm{p}<0.05)$.

The results of the above study indicate that the accounting cycle learning media assisted by an androidbased application can be declared effective. This is indicated by the difference in average learning outcomes and learning motivation between students who use the application and those who do not. Students who use the application have better learning outcomes and learning motivation than those who do not use the application. The results of these trials are in line with several studies [5] [2] [16], which shows that technology-based learning media can improve learning outcomes and make learning more interesting and fun. This has an impact on improving student academic performance.

\section{CONCLUSION}

The conclusions in this study include (1) the androidbased accounting cycle learning media has been successfully developed with an assessment of material aspects and media aspects that are considered feasible to use. (2) The use of android-based accounting cycle learning media has been shown to have a positive effect on students. The test results show that students who are given learning using application media have better academic performance.

Suggestions that can be submitted related to research is that learning media can be developed in other accounting topics. This can be seen from the enthusiasm of students who are more enthusiastic in learning by using technology. In addition, this media can also be further developed by adding an assessment feature that can be directly accessed by lecturers. So far, lecturers check student work manually, so that in the future a feature can be designed that can directly monitor student activities in using the application. 


\section{REFERENCES}

[1] Abdul Latip, "Peran Literasi Teknologi Informasi Dan Komunikasi Pada Pembelajaran Jarak Jauh Di Masa Pandemi Covid-19," EduTeach J. Edukasi dan Teknol. Pembelajaran, vol. 1, no. 2, pp. 108-116, 2020, doi: 10.37859/eduteach.v1i2.1956

[2] K. Watty, J. McKay, and L. Ngo, "Innovators or inhibitors? Accounting faculty resistance to new educational technologies in higher education," $J$. Account. Educ., vol. 36, pp. 1-15, Sep. 2016, doi: 10.1016/j.jaccedu.2016.03.003.

[3] J. Herrington, New technologies, new pedagogies: mobile learning in higher education. University of Wollongong, 2009.

[4] Bbc.com, "pelajar indonesia jadi salah satu pengguna tertinggi teknologi di dunia," https://www.bbc.com/indonesia/majalah46500293, 2019.

[5] R. Yektyastuti and J. Ikhsan, "Pengembangan Media Pembelajaran Berbasis Android pada Materi Kelarutan untuk Meningkatkan Performa Akademik Peserta Didik SMA," J. Inov. Pendidik. IPA, vol. 2, no. 1, pp. 88-99, 2016, doi: 10.21831/jipi.v2i1.10289.

[6] M. A. Mohd Thas Thaker, M. O. Mohammed, J. Duasa, and M. A. Abdullah, "The Behavioral Intention of Micro Enterprises to Use the Integrated Cash Waqf Micro Enterprise Investment (ICWME-I) Model as a Source of Financing," Gadjah Mada Int. J. Bus., vol. 18, no. 2, p. 111, Aug. 2016, doi: 10.22146/gamaijb.12565.

[7] Y. Wahyuliani, U. Supriadi, and S. Anwar, "Efektivitas Penggunaan Media Pembelajaran Flip Book Terhadap Peningkatan Hasil Belajar Siswa Pada Mata Pelajaran Pai Dan Budi Pekerti Di Sma Negeri 4 Bandung," TARBAWY Indones. J. Islam. Educ., vol. 3, no. 1, p. 22, 2016, doi: 10.17509/t.v3i1.3457.

[8] G. J. McVay, P. R. Murphy, and S. W. Yoon, "Good practices in accounting education: Classroom configuration and technological tools for enhancing the learning environment," Account. Educ., vol. 17, no. 1, pp. 41-63, 2008, doi: 10.1080/09639280600843369.

[9] P. de Lange, T. Suwardy, and F. Mavondo, "Integrating a virtual learning environment into an introductory accounting course: Determinants of student motivation," Account. Educ., vol. 12, no. 1, pp. 1-14, 2003, doi: $10.1080 / 0963928032000064567$.

[10] N. T. Herawati, L. G. K. Dewi, and G. A. K. R. S. Dewi, "Development of Android-Based Accounting Cycle Learning Applications to Improve Technology Skills in Accounting Students," vol. 158, no. Teams, pp. 98-104, 2020, doi: 10.2991/aebmr.k.201212.013.

[11] V. Pratiwi and D. S. Siswandari, "Mobile application based multimedia: A design of accounting instructional media for vocational high school (VHS)," in ACM International Conference Proceeding Series, Oct. 2018, pp. 330-334, doi: 10.1145/3290511.3290536.

[12] Trianto, Mendesain Model Pembelajaran Inovatif-Progresif, Edisi Pert. Jakarta: Kencana Prenada Media, 2009.

[13] N. Dantes, Metode Penelitian. Yogyakarta: Penerbit Andi, 2012.

[14] I. M. Candiasa, Statistik Multivariate Disertai Aplikasi SPSS. Singaraja: Undiksha Press, 2011.

[15] I. Ghozali, Analisis Multivariate dengan Program IBM SPSS 2.0, Badan Pene. Semarang, 2001.

[16] M. Sobri, "Efektivitas Pembelajaran Media ELearning Berbasis Web Dan Konvensional Terhadap Tingkat Keberhasilan Belajar Mahasiswa (Studi Kasus Mahasiswa Fakultas Ekonomi Universitas Bina Darma Palembang)," J. Chem. Inf. Model., vol. 53, no. 9, pp. 16891699, 2013. 